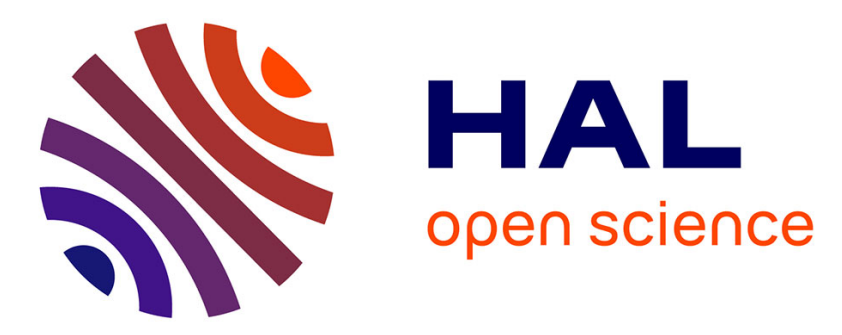

\title{
Tracing and analytical results of the dioxin contamination incident in 2008 originating from the Republic of Ireland
}

Lourens Heres, Ron Laurentius Hoogenboom, Rik Herbes, Wim Traag, Bert Urlings

\section{To cite this version:}

Lourens Heres, Ron Laurentius Hoogenboom, Rik Herbes, Wim Traag, Bert Urlings. Tracing and analytical results of the dioxin contamination incident in 2008 originating from the Republic of Ireland. Food Additives and Contaminants, 2010, 27 (12), pp.1733-1744. 10.1080/19440049.2010.522598. hal-00644272

\section{HAL Id: hal-00644272 \\ https://hal.science/hal-00644272}

Submitted on 24 Nov 2011

HAL is a multi-disciplinary open access archive for the deposit and dissemination of scientific research documents, whether they are published or not. The documents may come from teaching and research institutions in France or abroad, or from public or private research centers.
L'archive ouverte pluridisciplinaire HAL, est destinée au dépôt et à la diffusion de documents scientifiques de niveau recherche, publiés ou non, émanant des établissements d'enseignement et de recherche français ou étrangers, des laboratoires publics ou privés. 


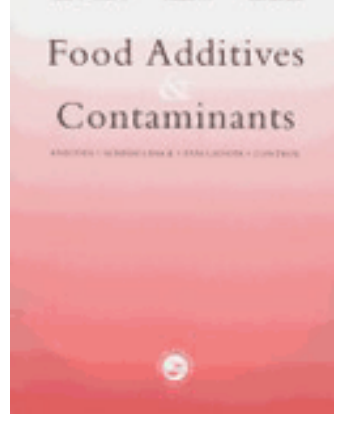

\section{Tracing and analytical results of the dioxin contamination incident in $\mathbf{2 0 0 8}$ originating from the Republic of Ireland}

\begin{tabular}{|r|l|}
\hline Journal: & Food Additives and Contaminants \\
\hline Manuscript ID: & TFAC-2010-165.R1 \\
\hline Manuscript Type: & Original Research Paper \\
\hline Date Submitted by the & O6-Sep-2010 \\
\hline Complete List of Authors: & $\begin{array}{l}\text { Heres, Lourens; VION Food Group } \\
\text { Hoogenboom, Ron; RIKILT-Institute of Food Safety, Safety and } \\
\text { Health } \\
\text { Herbes, Rik; Food and Consumer Products Safety Authority (VWA) } \\
\text { Traag, Wim; RIKILT-Institute of Food Safety, Safety and Health } \\
\text { Urlings, Bert; VION Food Group; Wageningen University, Animal } \\
\text { Sciences Group }\end{array}$ \\
\hline Methods/Techniques: & Traceability, Risk assessment, Screening assays, Regulations \\
\hline Additives/Contaminants: & Dioxins, Dioxins - TEQs, PCBs \\
\hline Food Types: & Meat, Animal feed, Animal products - meat, Ingredients \\
\hline &
\end{tabular}

\section{SCHOLARONE ${ }^{\text {M }}$ Manuscripts}




\title{
Tracing and analytical results of the dioxin contamination incident in 2008 originating from the Republic of Ireland
}

Lourens Heres $^{1 *}$, Ron Hoogenboom ${ }^{2}$, Rik Herbes ${ }^{3}$, Wim Traag ${ }^{2}$, and Bert Urlings ${ }^{1,4}$

1 VION Food Group; Ekkersrijt 7005 - 7023, 5692 HB, Son en Breugel, The Netherlands

2 RIKILT Institute of Food Safety; Wageningen UR; Akkermaalsbos 2, 6708 WB, Wageningen, The Netherlands

3 Food and Consumer Products Safety Authority; (VWA), P.O. Box 19506, 2500 CM Den Haag, The Netherlands

4 Animal Sciences Group; Wageningen UR; Marijkeweg 40, 6709 PG Wageningen, The Netherlands

*author for correspondence

Lourens Heres

Lourens.heres@vionfood.com

$+31-615098873$

\begin{abstract}
High levels of dioxins (PCDD/Fs) in pork were discovered in France and the Netherlands at the end of 2008. The contamination was rapidly traced back to a feed stock in the Republic of Ireland (RoI). Burning oil, used for drying of bakery waste, appeared to be contaminated with PCBs. As a consequence, very high levels up to $500 \mathrm{pg} \mathrm{TEQ} \mathrm{g}^{-1}$ fat were found in pork. The congener pattern clearly pointed to PCB-oil as a source but the ratio between the non-dioxin-
\end{abstract}


like indicator PCBs (PCBs 28, 52, 101, 138, 152 and 180) and PCDD/Fs was much lower than observed during the Belgian incident, thereby limiting the suitability of indicator PCBs as a marker for the presence of dioxins and dioxin-like PCBs.

This paper describes the tracking and tracing of the incident, the public-private cooperation, the surveillance activities, and its results. A major lesson to be learned from this incident is the importance of good private food safety systems. In this incident, it was the private surveillance systems that identified the origin of contamination within 10 days after the first signal of increased dioxin levels in a product. On the other hand, retrospective analyses showed that signals were missed that could have led to an earlier detection of the incident and the source. Above all, the incident would not have occurred when food safety assurance systems had been effectively implemented in the involved feed chain.

It is discussed that besides primary responsibility for effective private food safety systems, the competent authorities have to supervise whether the food safety procedures are capable of coping with these kinds of complex food safety issues, while private food companies need to implement the law, and public authorities should supervise and enforce them. Finally it is discussed whether the health risks derived from consumption of the contaminated batches of meat may have been underestimated during the incident, due to the unusually high intake of dioxins.

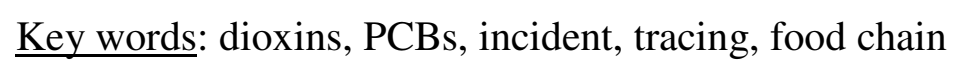

Running Title: Dioxin incident pork 2008. 


\section{Introduction}

Dioxins, i.e. polychlorinated dibenzo-p-dioxins and furans (PCDD/Fs), and dioxin-like polychlorinated biphenyls (dl-PCBs) remain a major threat for the consumer and as a result for the food chain. This is due to their accumulation in the body and large array of potential effects to human health. To provide guidance, limits for chronic exposure of consumers (Tolerable Weekly Intake, TWI) has been derived by the Scientific Committee on Food (SCF, 2001). Within the legislation maximum levels in food and feed products were set to reduce exposure of consumers below the TWI (EC 2006a, 2006b). PCDD/Fs may be derived from a large number of different sources, like the incineration of waste, production of certain chlorinated compounds but also the burning or heating of polychlorinated biphenyls (PCBs). For example, during the past decade incidents were observed with citrus pulp using lime from a plant producing polyvinyl chloride (PVC-) (Malisch et al. 2000), feed fat contaminated with PCB-oil in Belgium (Bernard et al. 1999, Hoogenboom et al. 1999, Van Larebeke et al. 2001), cholin chloride mixed with pentachlorophenol treated sawdust (Llerena et al. 2003), sequestered minerals produced from seaweed, bakery waste dried over fires from painted wood (Hoogenboom et al. 2004a), peels from potatoes sorted in a bath containing kaolinic clay with high levels of dioxins from an ancient source (Hoogenboom et al. 2010), and feed fat derived from a gelatine production plant using hydrochloric acid $(\mathrm{HCl})$ contaminated by a still unrecovered source (Hoogenboom et al. 2006). In 2008 there was an incident with contaminated zinc-oxide in Chile that caused the long-term closure of the borders of Korea and Japan for Chilean pork (Kim et al. 2009). This long list of incidents shows that frequent monitoring of food and feed is required to detect gaps and weaknesses in chain control and to detect incidents and their sources as early as possible in order to protect human health and prevent large economic losses. At the same time, this is hampered by the large number of different sources that make a targeted monitoring approach for dioxins rather difficult. 
However, an efficient control of these contaminants is essential to reduce the exposure to the population.

The present paper describes how private food quality systems led to the discovery of another dioxin incident at the end of 2008. Surveillance by the food business operator (FBO) led to the rapid identification of the source. The incident is described from the stage where the contamination was detected at a meat producer and where the origin was fully unknown, towards a stage where all evidence, including characterisation of the PCDD/F profiles, pointed to the Republic of Ireland (RoI) as the origin of the contamination and PCBs as the source. An estimate is made about the contamination levels that occurred. Besides describing the incident, this paper aims to show the effect of efficient public and private sector cooperation that led in this case to a rapid identification of the origin. Finally opportunities for improvement in HACCP and surveillance systems for chemical contaminants are identified.

\section{Materials and methods}

\section{Case description}

\section{Onset}

A French meat processor (Company A) reported the contamination of pork with dioxins to their supplier (Company B) on Monday November $24^{\text {th }} 2010$. At this point Company B reported the incedent to Company C, Company B's parent Company. The tested product was a deboned loin from a batch of $1557 \mathrm{~kg}$, received in France on October $14^{\text {th }}$. On November $25^{\text {th }}$ in the late afternoon Company A sent a detailed analytical report to company $\mathrm{C}$. This report included the PCDD/F congeners and showed a contamination level of 433 pg dioxin toxic equivalents (TEQ)/g fat. In addition the sample also contained an elevated level of dioxin-like PCBs (16 pg TEQ g ${ }^{-1}$ fat). Indicator PCBs (PCBs 28, 52, 101, 138, 153, 180) were not determined but the typical furan pattern pointed to PCBs as the source. 


\section{Follow-up actions}

Immediately after receiving the first information about the contaminated pork sample, several actions were taken by Companies B and C. Tracking and tracing was started, a surveillance of the contamination was initiated, the competent authority (CA) was immediately informed, and information was acquired from plants processing the slaughter by-products.

\section{Tracking and tracing}

Company B is a meat production company in the south of The Netherlands that slaughtered about 600 sows per day, mainly from Dutch and partly from Belgium origin. Additionally, it received external supplies (mainly carcasses) from other companies on a daily basis. Approximately 1000 carcasses were cut and deboned daily.

Like in many deboning facilities tracking and tracing in the deboning area was based on production day batches. From each day it is know which carcasses are deboned, which and how many products are cut from these carcasses, and where and when these products are sold or stored. Tracing showed that the contaminated loin was produced on October $13^{\text {th }}$. On this day, 1049 carcasses were deboned originating from 7 countries of the European Union (EU) and 9 slaughterhouses (Netherlands (2), Belgium, Germany (2), England, Northern Ireland, Republic of Ireland (RoI), and Italy). The sows were slaughtered on different days (Table 1). Tracking showed that 70 customers obtained meat from production of October $13^{\text {th }}$. Meat produced on this date was in several shipments summing up to 400 tonnes, due to combination of products from earlier and later production dates.

Following the initial notification, products from October $13^{\text {th }}$ that were still in possession of company B were tracked and placed on hold. Frozen stock was shipped back to the cutting and deboning facility and samples were taken from the remaining products. From the pallets 
with meat from different sources, 1 pool sample per pallet was collected. The samples collected on November $25^{\text {th }}$ were analyzed by a private laboratory for indicator PCBs. A second set of samples was collected on November $26^{\text {th }}$ and tested for PDCC/Fs and dl-PCBs using gas chromatography / mass spectrometry (GC/MS). These two sets of samples were negative. In a third sampling of December $2^{\text {nd }}$ with 10 pooled samples, one sample showed a positive test result in the so-called CALUX-bioassay (Chemical Activated LUciferase gen eXpression), a screening assay for dioxin-like compounds. This sample showed a confirmed PCDD/F content of $1.9 \mathrm{pg}$ TEQ $^{-1}$ fat. This is relatively low but higher than the normal background of $0.1 \mathrm{pg}$ TEQ $\mathrm{g}^{-1}$ fat.

\section{Private Surveillance of new shipments}

Following the notification, there was a possibility that the contaminated pork originated from Dutch farms. Therefore, a surveillance program was started by company $\mathrm{C}$ to investigate this possibility. The 175 Dutch farms that were identified as the possible origin of the contaminated supply were listed for surveillance. Samples were taken from the next deliveries coming from these farms of up to 5 pigs. Both sows and fattening pigs were sampled. This Surveillance was started on November $27^{\text {th }}$. In total 149 supplies to Dutch slaughterhouses were sampled within 7 days, i.e. 646 pigs and sows. Herds were released when no sample showed a positive result and at least 3 samples were tested on PCB's.

At the same time, the supply of carcasses from foreign origin was continued and all carcasses were sampled by pooling 10 carcasses in one sample. Nine freights with on average 138 carcasses were supplied, 6 from England, 1 from Northern Ireland and 2 from the RoI. The two German slaughterhouses that supplied carcasses for the production on October $13^{\text {th }}$ to company B belonged to the same parent company. Therefore an equivalent surveillance system was introduced into these slaughterhouses. 


\section{Information and cooperation with authorities}

The CA of the Netherlands (Food and Consumer Products Safety Authority, VWA) were informed during the morning of November $25^{\text {th }}$, with regard to the oral incident report of the dioxin finding by company A at the previous day. Company $\mathrm{C}$ and the VWA, together with an expert of RIKILT had a meeting on December $3^{\text {rd }}$. The actions taken by company B and C were discussed with respect to appropriateness and extend of the implemented measures. In this meeting it was concluded that the PCDD/F congener profile in this case was to a certain level comparable with the Belgium dioxin case of 1999, where PCDD/Fs and PCBs were both elevated. The ratio of indicator PCBs and PCDD/Fs was however much lower (Table 3). The approach of the company to test for indicator PCBs for the further unravelling of this case was approved, as the participants agreed that high levels of dioxins were to be expected and as such also clearly elevated levels of indicator PCBs.

The VWA stayed in close contact with company $\mathrm{C}$ and was informed about the surveillance, tracking and tracing actions of the company, and supervised the actions taken. The authorities were immediately informed about the suspected positives in the PCB test of 
RoI origin on December $5^{\text {th }}$. As soon as these samples were confirmed by the RIKILT to contain high levels of PCDD/Fs, the VWA informed their colleagues of the Irish Food Safety Authority (FSAI), as well as the European Rapid Alert System for Food and Feed (RASSF) on Saturday December $6^{\text {th }}$. At this stage it turned out that the authorities from RoI had detected elevated indicator PCB levels in pork and as a result had quarantined a number of pig farms (Tlustos 2009).

Officials from the EU, the RoI and the Netherlands had a telephone conference to discuss all findings, including all test results of Company B on December $6^{\text {th }}$. During that evening a full recall of RoI pork was announced by the RoI competent authority (Tlustos 2009a,b).

\section{Collection of supply chain data}

On December $3^{\text {rd }}$, increased concentrations of dioxins in pork fat above legal limits were reported by a gelatine processing plant in Ghent, Belgium. This company processes pig skins for the production of gelatine and produced pig fat for animal feed as a by-product. Since the incident in 2006 (Hoogenboom et al. 2007) this fat had to be checked for dioxins. The level of PCDD/Fs in fat increased from the second half of September and onwards (figure 1A) but exceeded the legal limit only in week 48. Tracing showed that the raw material for this byproduct weighed around 600 metric tonnes for each batch, and originated from various countries from several pig slaughter and deboning sites (table 2).

The first increased dioxin level was seen in a sample of September $12^{\text {th }}$. This was from pig skins obtained in the first weeks of September. This sample showed a PCDD/Fs level around 1.4 $\mathrm{pg}^{\mathrm{TEQ}} \mathrm{g}^{-1}$ fat, i.e. below the legal limit of $2 \mathrm{pg}^{\mathrm{TEQ}} \mathrm{g}^{-1}$ fat. However, in normal situations the levels are below the detection limit of 0.3 pg TEQ $\mathrm{g}^{-1}$ fat. At the end of November (week 48) a sample contained PCDD/Fs above the legal limit of $2 \mathrm{pg}$ TEQ $/ \mathrm{g}^{-1}$ fat for feed materials, i.e. the level was $3.7 \mathrm{pg} \mathrm{TEQ} / \mathrm{g}^{-1}$ fat. This simultaneous occurrence of 
increased dioxin levels in pork and fat again indicated that a serious dioxin contamination was taking place somewhere in Europe. The congeners profile showed a comparable distribution of congeners with the meat sample of company A which was a strong argument for one source of contamination.

The tracing results of the fat from this gelatine plant were analyzed afterwards, during evaluation of the incident. From most batches with elevated dioxin levels the tracing results were known (see figure 1). Based on this data Poland, Belgium and Austria could be excluded as source of the contamination with the results of end October, because suppliers of pig skin from these countries had not supplied skin for two or more batches of fat with more than $1 \mathrm{pg}$ TEQ $\mathrm{g}^{-1}$ (see figure 1B). The United Kingdom (UK) seemed a less probable source as it was absent as supplying country from the tank sampled at October $13^{\text {th }}$ with elevated dioxin levels, and most peaks in UK supplies did not coincide with peaks of dioxins. However a definite conclusion about UK could not be made. Firstly because in all tanks with elevated dioxin levels, skin fat from UK pigs was present. Secondly the levels of dioxins decreased at the beginning of November, a period in which the supplies from UK and RoI were lower than average. And finally in the sample from November $24^{\text {th }}$ with a high dioxin level supplies from UK and RoI were twice as high as normal (15\%).

German and Dutch supplies were present in all fat samples and could therefore not be excluded as source. The amount of raw material from the RoI correlates well with the levels of dioxin in the fat samples (figure 1B), but this is only a causal relationship in hindsight. Henceforth, a fully conclusive result about the country of origin was not possible on the supply of the gelatine plant. The main cause is that the amount of skin used for the production of the batches with fat is extremely large, and the amounts supplied are relatively constant for all suppliers. An intensified targeted surveillance stratified on country or regions of origin (Germany, The Netherlands, UK and RoI) could have been initiated at the end of October 
after observing a number of batches with elevated dioxin levels. This might have given more certainty about the country of origin, probably by mid November.

On November $27^{\text {th }}$ another fat melting company was informed about the dioxin case, and was asked to test stored fat samples from October from by-products partly originating of company B. In one plant within the firm that processed bones, elevated PCB levels were observed in fat samples collected in the last two weeks of November, but not in the preceding weeks. The sum of PCBs was $<64 \mathrm{ng} \mathrm{g}^{-1}$, which is higher than normal but not exceeding current legal limits. Results were available after identification of RoI as the source of the contamination and therefore no further sourcing was done.

\section{Contamination levels}

From the observed levels of dioxins in positive samples, the contamination levels in tainted pigs can be deduced. In the Index pork loin analysed in France on behalf of company A, a dioxin content of $433 \mathrm{pg}^{\mathrm{TEQ}} \mathrm{g}^{-1}$ fat was reported. This sample was derived from 1 contaminated animal.

The Irish carcasses detected as positive by company B were from pigs slaughtered on November $28^{\text {th }}$. The 230 carcasses were sent with two trucks. All samples from the first truck were negative (11 pooled samples). From the second truck, 7 out of 12 pooled samples were positive. The Real Prevalence can be estimated from the pool prevalence by the following equation: $\mathrm{P}_{\text {estimated }}=1-\left(1-\mathrm{P}_{\text {pool }}\right)^{\wedge}(1 /$ number in pool $)($ Cowling et al, 1999). A pool prevalence of 7 out of 23 gives an estimated fraction of contaminated carcasses of $3.6 \%$, or about 8 tainted carcasses in the shipment of 230 . If so, there was on average one positive carcass per positive pool, and a limited number of pools with 2 or 3 positive carcasses. Since the pooled samples were derived from 10 different carcasses from RoI sows, the actual level in an individual carcass must be higher than that from the pooled sample. With varying 


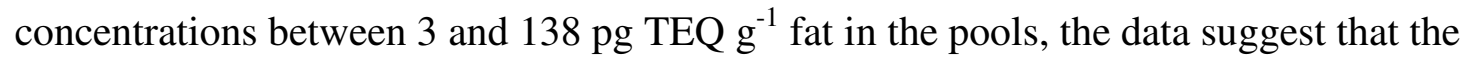
contamination level in the contaminated sows was on average $300 \mathrm{pg}^{\mathrm{TEQ}} \mathrm{g}^{-1}$ fat. This was more or less confirmed by follow-up analysis of non-pooled pork samples from RoI at the RIKILT, showing a highest level of $540 \mathrm{pg}^{\mathrm{TEQ}} \mathrm{g}^{-1}$ fat.

The average contribution of RoI pig skin in the gelatine production was $7 \%$. When the concentration in the fat after gelatine production is recalculated by dividing the concentration by the percentage of RoI skin, a steady but fluctuating increase in concentration is seen towards $25 \mathrm{pg}^{\mathrm{TEQ}} \mathrm{g}^{-1}$ fat. Assuming an average of $10 \%$ contaminated pigs in the RoI cohort (as was stated by the RoI authorities, Tlustos et al. 2009), the average dioxin concentration in fat from contaminated pig would have been around $250 \mathrm{pg}^{\mathrm{TEQ}} \mathrm{g}^{-1}$ fat. This is relatively close to the contamination level found in the index pork loin, the levels estimated from the pooled samples and the levels measured later in individual pigs.

The RoI government announced the observation of elevated levels of dioxins and PCBs in beef as well, but levels were not published (Tlustos 2009). During the incident the highest level however, was detected in pork liver in Poland and confirmed by the Community Reference Laboratory (CRL) on dioxins (annual report 2008, CVUA, Freiburg), showing a level of $16,000 \mathrm{pg}$ TEQ $\mathrm{g}$ fat $^{-1}$.

\section{Source of the RoI incident}

The RoI authorities reported in consultation with the VWA that the use of contaminated bread crumbs in animal feed was identified to be the source. The bread crumbs were produced from bakery waste, like biscuits out of date, which were dried using a direct heating process. In such a process, the combustion gasses are in direct contact with the feed material to be dried. The fuel used in this process was contaminated with PCB transformer oil. In June/July 2008 the management of the factory that produced dried bread crumbs had decided to switch to 
cheaper fuel in response to the increasing fuel prices. After burning, this resulted in high levels of dioxins in the combustion gasses which were deposited on the material to be dried. The fuel oil was originating from UK (Northern Ireland) but it was not disclosed thus far at which stage the PCB transformer oil was added to the fuel.

All possibly contaminated feed was traced and placed on hold. Also all animals on the affected farms in RoI and UK (Northern Ireland) were held for being disposed of safely (source SCoFCAH 19-20 January 2009). All pork produced between $1^{\text {st }}$ September and the $6^{\text {th }}$ of December was recalled from the shops.

\section{PCB and dioxin profiles in pork, bread crumbs and oil}

In the following part of this paper the congeners profiles of different positive samples from this dioxin incident are compared. Suspected samples from company B and from the gelatine production plant were sent to WUR-RIKILT, the Dutch Reference laboratory for dioxins and PCBs. Later on RIKILT received one sample of contaminated bread crumbs and one sample of oil used from drying the crumbs from the Irish authorities. Samples were analyzed as described previously (Hoogenboom et al. 2007), based on the extraction of fat with ASE (bread crumbs), the purification on a Powerprep ${ }^{\mathrm{TM}}$ system (FMS Inc.) and the analysis by HRGC/HRMS.

\section{Pig meat and fat}

RIKILT analysed the 7 pooled RoI carcass samples by GC/MS and measured levels between

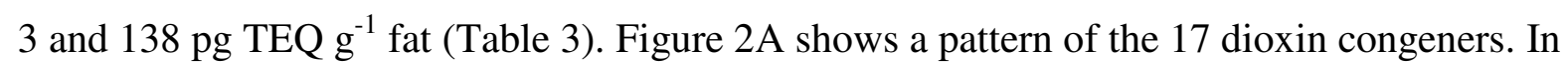
terms of contribution to the TEQ-level, 2,3,4,7,8-PeCDF was by far the most important congener (about 85-90\%). The samples also contained elevated dl-PCBs, contributing about 3-5\% to the total TEQ levels, and also indicator PCB-levels. The ratio between the sum of the 
7 indicator PCBs and the dioxin TEQ varied between 2000 and 4000, being much lower than the ratio of 50,000 observed during the Belgian dioxin and PCB incident in 1999 (Hoogenboom et al. 2004b). In that incident $200 \mathrm{~kg}$ of PCB-oil had been mixed directly with 60 tonnes of fat that was used for the production of animal feed. It seems likely that the burning process increased the amount of PCDFs and as such decreased the ratio of indicator PCBs and PCDD/Fs.

Figures $2 \mathrm{~B}$ and $2 \mathrm{C}$ show patterns of the dl- and indicator PCBs. The relative contribution of PCB 180 is higher than in the feed in the '99 Belgian incident (30 versus 10\% (Hoogenboom et al. 2004b)). Also PCB 156 contributed to a higher extent in comparison to PCB 118. This data indicates that the PCB-oil in this case was higher chlorinated than the Arochlor 1254/1260 mixture in the Belgian incident, pointing to an Arochlor 1260 mixture. This information was passed to the RoI authorities shortly after confirmation that RoI was the origin of the contaminated pork.

\section{Fat from a gelatine plant}

Since the gelatine incident in 2006 (Hoogenboom et al. 2007), caused by hydrochloric acid contaminated with dioxin, the fat should be checked for dioxins. Levels are normally below $0.3 \mathrm{pg}$ TEQ/g fat. Several of the samples from the Belgium gelatine plant were reanalyzed by RIKILT and showed a congener pattern similar to the pattern observed in the meat samples (Figure 2).

\section{Bread crumbs}

The sample of contaminated bread crumbs showed a dioxin level of $8500 \mathrm{ng}$ TEQ kg${ }^{-1}$, in addition to $60 \mathrm{ng}$ TEQ $\mathrm{kg}^{-1}$ of the dl-PCBs and $1.4 \mathrm{mg} / \mathrm{kg}$ of the six indicator PCBs (Table 3). The ratio between indicator PCBs and dioxin-TEQs in this material was only 166 . The pattern 
of the congeners is included in Figure 2. A remarkable point was the relatively high contribution of TCDF and 1,2,3,7,8-PeCDF to the TEQ, as compared to the pork meat. These congeners, however, are known to be rather unstable in pigs (Hoogenboom et al. 2004b).

\section{Contaminated oil}

The real source of the contamination was the oil used for the drying of the bread crumbs. A sample of contaminated oil showed a level of the six indicator PCBs of $306 \mathrm{mg} / \mathrm{kg}$. Since these congeners make up only part of the mixture, the actual PCB level in the oil may be $2-4 x$ higher. The PCB pattern in this sample was very similar to that of the bread crumbs (Figure 2C). The dioxin level was below $22 \mu \mathrm{g}$ TEQ $\mathrm{kg}^{-1}$. Although the detection limit was rather high, due to the small sample intake, it is clear that the relative amount of PCDD/Fs is much lower than in the bread crumbs (ratio $>14,000$ ) and that most of the dioxins may have been formed during the burning of the oil resulting in transformation of the PCBs in the oil.

\section{Discussion}

\section{Practical lessons}

As in this case, most of the time food business operators are looking in the dark when they receive a report indicating high levels of chemical substances in one of their products, especially when there is no other information in the supply chain indicating a contamination accident somewhere. In this case the batch sizes were large, there were several slaughterhouses of possible origin and the supplying farms were a multitude. Introduction of limited batch sizes and batch-wise processing of meat from different origin would facilitate traceability in these kinds of incidents markedly. 
Decisions to continue supply and to sample the incoming carcasses were in this case of crucial importance to identify the source of the contamination. In combination with the negative test results in pigs from Dutch and German origin, there was a high certainty about the origin of contamination after finding a few positive RoI carcasses.

The parallel identification of dioxin contaminations in fat produced at the gelatine production site helped to conclude that the finding was not an incident and that RoI could be the country of origin, but also indicated that the actual onset of the contamination started in September 2008. When the levels of dioxins increased and exceeded the EU action limit for PCDD/Fs of $1 \mathrm{pg}^{\mathrm{TEQ}} \mathrm{g}^{-1}$ fat, the company had started to investigate the source, for example by testing the added salt. But an earlier report to other parties in the supply chain could have initiated broader awareness. Identifying the country of origin at this big gelatine production side was complicated, because the large batches of fat produced originate from raw materials from different collectors, from different countries, and from different production days. Consequently, most of the suppliers supplied to every batch. Nevertheless, at the end of October some supplying countries could be excluded and a targeted surveillance at regional level could have identified RoI, possibly by the beginning of November.

In the surveillance applied in this incident, indicator PCBs were used for screening and samples were pooled. In the dioxin crisis in Belgium in 1999 the indicator PCB/dioxin TEQ ratio was 50.000 to 1 . In this RoI situation it was 2000 - 4000 to 1 , at least in the pigs. In the positive loin (Company A) a contamination level of $433 \mathrm{pg}$ TEQ dioxins $\mathrm{g}^{-1}$ fat was found. At this high level, also the PCB levels (1200 $\mathrm{ng} \mathrm{g}^{-1}$ fat) were far above legal limits. At lower dioxin levels, for example 5 pg TEQ $\mathrm{g}^{-1}$ (which is 5 times above the legal limit), PCB levels could be at, or below $15 \mathrm{ng} \mathrm{g}^{-1}$, which is the newly proposed EU limit of $15 \mathrm{ng} \mathrm{g}^{-1}$ fat but far below existing national legal limits. More important, such levels are below the limit of detection for many routine laboratories and cannot prove that products are compliant with the 
legal limits for dioxins. However, in this case this suboptimal detection sensitivity was good enough for detection of highly contaminated samples (tracking and tracing) and could overcome the limited availability of test capacity for dioxin.

The contamination was shown to be originating from uncontrolled feed production by burning PCB contaminated oil. Since 2006 all feed business operators are legally obliged to incorporate HACCP-requirements in their quality systems. Looking at the hazards and risks of direct combustion and the use of unspecified oil, a monitoring system on PCBs and dioxins should be integrated in the companies own quality system. In assured GMP based feed production the risk of such contamination scenario's are minimized. Such a food safety system was however not in place at the feed producer of concern.

\section{Risk assessment}

In order to decide on the appropriate risk management actions and to inform and reassure consumers, it is essential to evaluate the potential health risks arising from the consumption of contaminated products. On December $10^{\text {th }} 2008$, The European Food Safety Authority (EFSA, 2008) published a risk assessment on the incident. The main conclusion was that the additional exposure due to dioxin contamination was a minimal risk. Consumption of contaminated pork clearly resulted in a high temporary exceeding of the exposure limit (TWI) of 14 pg TEQ per kg bw per week, as established by the SCF (2001). However, the TWI is set for a chronic rather than an acute exposure, aiming at keeping the levels in the body (body burden) below the critical levels. Therefore, EFSA also estimated the possible effect of the exposure on the already existing dioxin and dl-PCB levels in the body. It was concluded that continuous consumption of contaminated pork would contribute significantly to the existing body burden. However, "in a more likely scenario with a daily consumption of $10 \%$ contaminated RoI pork for an average consumer of pork fat for the respective period of the 
incident (90 days) at the highest recorded concentration of dioxins (200 pg WHO-TEQ $\mathrm{g}^{-1}$ fat), the body burden would increase by approximately 10\%”. EFSA considered this increase in body burden of no concern for this single event.

Based on data on the number of affected farms (Tlustos 2009a), the 10\% contaminated RoI pork seems a realistic assumption. The levels of 50, 100 and 200 pg TEQ $\mathrm{g}^{-1}$, used for the assessment, however, may be a clear underestimation, because higher levels were found in the index loin (433 pg TEQ/g) and also the pooled samples in The Netherlands indicated higher individual levels (around $300 \mathrm{pg}$ TEQ g$^{-1}$ fat). Moreover, the high levels in the meat also pointed to the possibility of high levels in the liver, an effect well-known in rats exposed to high levels of dioxins (Hurst et al. 2000a, Bell et al. 2007c). Own data in pork from one of the latest dioxin incidents showed e.g. a ratio of 4 to 8 between the dioxin levels in the liver and in back fat, expressed per g of fat. This possibility was confirmed by CVUA (2008) reporting one liver sample containing $16,400 \mathrm{pg}$ TEQ $^{-1}$ fat. Based on $5 \%$ fat this would amount to about 800 pg TEQ g $^{-1}$ liver.

Another important issue that was not covered in the EFSA assessment is the potential effect of a peak exposure resulting from the consumption of a highly contaminated food product. Normally, levels expressed on a fat base are in equilibrium between adipose tissue and blood. As a result most of the dioxins and dl-PCBs are stored in the body fat and less than $1 \%$ may be circulating in the blood. At a background body burden of 10-20 pg TEQ g ${ }^{-1}$ fat, the blood will contain an absolute amount of about 250-500 pg TEQ. A piece of $150 \mathrm{~g}$ pork meat with $10 \%$ fat and $600 \mathrm{pg}$ TEQ g $^{-1}$ would contain $9000 \mathrm{pg}$ TEQ, i.e. 18 times as much as

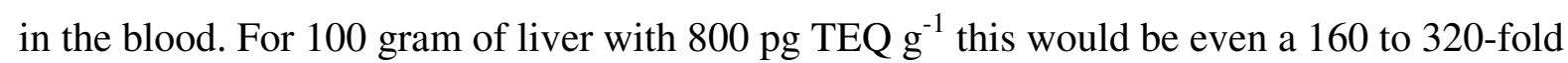
higher. Following consumption, these dioxins may therefore cause an increased level in the blood and as a result the temporarily increased exposure of sensitive tissues. This was confirmed by Hurst et al. (2000a, 2000b) showing that an acute exposure results in relatively 
higher levels in the foetus than a chronic exposure. Since fat tissue is a slowly perfused tissue, this situation may even last for a longer period of time (Hurst et al. 2000a). These data were used by the SCF (2001) to correct data from rat studies with single exposures in order to derive the TWI for chronic low exposure by increasing the critical body burden level by a factor 2.6. It is also appears that adverse effects in prenatal rats appear to occur from exposure during a relatively short time window (SCF 2001). Bell et al. (2007a, 2007b, 2007c) also compared an acute exposure with a chronic exposure in pregnant rats and confirmed that an acute exposure results in relatively higher exposure of the foetus. However, in these studies the chronic exposure resulted in a delayed puberty in male off-spring at much lower doses than in the pups of mothers exposed to a single high dose. In a recent review of the data, the authors argued that they might have missed the critical window in the single exposure or that the delayed puberty is actually caused postnatal, due to exposure through the milk (Bell et al 2010). In summary, it cannot be excluded that a peak exposure is relevant for the unborn exposed in utero. A re-evaluation of the existing data is required to evaluate the risk of an incidental high exposure. At this stage it seems wise to declare such high levels in future a clear food safety risk and to avoid such high exposures by preventive actions and adequate control of feed and food.

\section{Private and Public Co-operation}

The Dutch FBO (Company B) directly informed the positive dioxin finding of company A to their CA. The CA decided not to alert the public, but waited for more evidence and facts about the source of the contamination. In good co-operation and keeping the right responsibilities between $\mathrm{CA}$ and $\mathrm{FBO}$, the source of the contamination could be identified. In this case it was very valuable to have an open exchange on data, both analytical data as well as knowledge about previous dioxin contaminations. In this regard it was important to have 
also a close contact with the national reference laboratory for their knowledge on dioxins and also for a (very) quick confirmatory analysis of the samples positive in the CALUX-assay and showing elevated PCBs.

During this incident there was a very close contact between the Dutch and the RoI CAs from the first positive finding in The Netherlands (out of the monitoring of company B). With the available information from the Netherlands, the RoI CA could act faster since at that stage no dioxin results were available in RoI. Also sharing the information in an early stage with the European Commission was important to have a common strategy concerning the results and the situation. Normally the Rapid Alert System for Feed and Food is used to inform the EC and the other Member States of the EU, but this system is and should be used with objective data only. On the other hand the exchange of (fragmented) data outside this RASFF showed to be very valuable.

\section{Conclusions}

The incident with dioxin contaminated pork from the Republic of Ireland once again shows that serious dioxin incidents still occur, which may impose a heavy burden on the food chain.

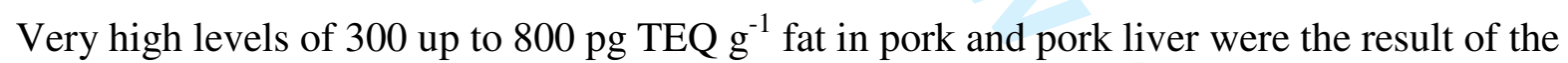
contamination of a relatively minor feed ingredient.

The described surveillance effort by the FBO demonstrates that good cooperation and exchange of data between food and feed business operators at different stages in the supply chain, and the official authorities and its bodies can lead to a fast tracing of the source of the contamination. The private surveillance systems in this case were able to identify the origin of contamination within 10 days after the first signal of increased dioxin levels in a product. This full responsive behaviour of FBOs is what is envisaged in the European legislation, where the 
General Food Law clearly states that the first responsibility for the production of safe food lays at the food and feed business operators.

This crisis nevertheless underlines that private quality systems might still have their weaknesses. The CAs should therefore enforce that every company implements an effective food safety system where this is not yet the case. And in times of crises they need to supervise whether the food producer is able to cope with these complex matters, and whether the HACCP-procedures are effective.

The small PCBs/dioxins ratio in this incident showed that analysis of indicator PCBs may not always be a valuable tool to identify dioxin contamination, even if PCBs are the source. Therefore a test detecting dioxins and dioxin-like PCBs must be considered as the preferred test for the detection of these compounds. However, the capacity of the official GC/HRMS method is still expensive and the capacity limited. When for that reason a PCB-tests and pooling of samples is applied the limitations of the alternatives should be taken into account. Routine screening with the $\mathrm{CALUX}^{\circledR}$ assay might be a better alternative, especially at low contamination levels.

Several other lessons to be learned were identified. The interval between the sampling of the meat, mid October, and the testing end November, could have been shorter, and could have reduced the exposure of consumers to dioxins. Secondly, the outbreak investigation showed that trend analysis of contamination in fat in a slaughter by-product processing plant is an effective way for surveillance of major dioxin contaminations in animal production. Prevention (integrated food and feed chain control) should require proper evaluation of production processes of feed ingredients. Special emphasis should be on drying processes as this is the second incident in five years with dried bakery waste (Hoogenboom et al. 2004a).

Last but not least a risk assessment is needed about the risk of incidental exposure to high levels of dioxins with special emphasise on potentially elevated dioxin levels in blood and 
increased dioxin exposure of sensitive tissues and the foetus. In new incidents this assessment should be available and should than be regarded with respect to recalls. 


\section{References}

Bell DR, Clode S, Fan MQF, Fernandes A, Foster PMD, Jiang T, Loizou G, MacNicoll A, Miller BG, Rose M, Tran L, White S. 2007a. Toxicity of 2,3,7,8-tetrachlorodibenzo-pdioxin in the developing male Wistar(Han) rat. I: No decrease in epididymal sperm after a single acute dose. Toxicological Sciences 99: 214-223.

Bell DR, Clode S, Fan MQF, Fernandes A, Foster PMD, Jiang T, Loizou G, MacNicoll A, Miller BG, Rose M, Tran L, White S. 2007b. Toxicity of 2,3,7,8-tetrachlorodibenzo-pdioxin in the developing male Wistar(Han) rat. II: Chronic dosing causes developmental delay. Toxicological Sciences 99: 224-233.

Bell DR, Clode S, Fan MQF, Fernandes A, Foster PMD, Jiang T, Loizou G, MacNicoll A, Miller BG, Rose M, Tran L, White S. 2007c. Relationship between levels of 2,3,7,8tetrachlorodibenzo-p-dioxin (TCDD), mRNAs, and toxicity in the developing male Wistar(Han) rat. Toxicological Sciences 99: 591-604.

Bell DR, Clode S, Fan MQF, Fernandes A, Foster PMD, Jiang T, Loizou G, MacNicoll A, Miller BG, Rose M, Tran L, White S. 2010. Interpretation of studies on the developmental reproductive toxicology of 2,3,7,8-tetrachlorodibenzo-p-dioxin in male offspring. Food and Chemical Toxicology 48: 1439-1447.

Bernard A, Hermans C, Broeckaert F, Poorter G de, Cock A de and Hoins, G. 1999. Food contamination by PCBs and dioxins; an isolated episode in Belgium is unlikely to have affected public health. Nature. 401: 231-232.

Bernard A, Broeckaert F, De Poorter G, De Cock A, Hermans C, Saegerman C, Hoins G. 2002. The Belgian PCB/dioxin incident: analysis of the food chain contamination and health risk evaluation. Environ. Res. Section. 88: 1-18.

CVUA. 2008. Jahresbericht 2008, page 77. 
Cowling DW, Gardner IA, Johnson WO, 1999. Comparison of methods for estimation of individual-level prevalence based on pooled samples. Prev. Vet. Med. 39: 211-225.

EC. 2006a. Commission regulation (EC) No 199/2006 amending Regulation (EC) No 466/2001 setting maximum levels for certain contaminants in foodstuffs as regards dioxins and dioxin-like PCBs. Off. J. Eur. Comm. L32: 34-38.

EC. 2006b. Commission directive 2006/13/EC amending Annexes I and II to Directive 2002/32/EC of the European Parliament and of the Council on undesirable substances in animal feed as regards dioxins and dioxin-like PCBs. Off. J. Eur. Comm. L32, 44-53.

EFSA. 2008. Statement of EFSA on the risks for public health due to the presence of dioxins in pork from Ireland. The EFSA Journal. 911: 1-15.

Hoogenboom LAP, Traag WA and Mengelers MJB. 1999. The Belgian dioxin crisis; involvement of RIKILT. Poster presented at Dioxin '99 in Venice, Italy.

Hoogenboom LAP. 2002. The Combined use of the CALUX bioassay and the HRGC/HRMS method for the detection of novel dioxin sources and new dioxin-like compounds. Environ. Sci. Pol. Res.. 9: 9-11.

Hoogenboom, LAP, Bovee TFH, Portier L, Bor G, Van der Weg G, Onstenk C and Traag WA. 2004a. The German bakery waste incident; use of a combined approach of screening and confirmation for dioxins in feed and food. Talanta. 63: 1249-1253.

Hoogenboom LAP, Kan CA, Bovee TFH, Van der Weg G, Onstenk C and Traag WA. 2004b. Residues of dioxins and PCBs in fat of growing pigs and broilers fed contaminated feed. Chemosphere 57: 35-42.

Hoogenboom LAP, Van Eijkeren JCH, Zeilmaker MJ, Mengelers MJB, Herbes R, Immerzeel J, Traag WA. 2007. A novel source for dioxins present in recycled fat from gelatin production. Chemosphere 68: 814-823. 
Hoogenboom R, Zeilmaker M, Van Eijkeren J, Kan K, Mengelers M, Luykx D, Traag W. 2010. Kaolinic clay derived PCDD/Fs in the feed chain from a sorting process for potatoes. Chemosphere 78: 99-105.

Hurst CH, DeVito MJ, Setzer RW and Birnbaum LS. 2000a. Acute administration of 2,3,7,8tetrachlorodibenzo-p-dioxin (TCDD) in pregnant Long Evans rats: association of measured tissue concentrations with developmental effects. Toxicol. Sci. 53: 411-420.

Hurst CH, DeVito MJ, and Birnbaum LS. 2000b. Tissue disposition of 2,3,7,8tetrachlorodibenzo-p-dioxin (TCDD) in maternal and developing Long-Evans rats following subchronic exposure. Toxicol. Sci. 57: 275-283.

Kim M, Choi S-W, Park JY, Kim D-G, Bong Y-H, Jang JH, Song SO, Chung GS, Guerrero P. 2009. Dioxin contamination of Chilean pork from zinc oxide in feed. Organohalogen. Comp. 71: 179-182.

Larebeke N van, Hens L, Schepens P, Covaci A, Bayens J, Everaert K, Bernheim J L, Vlietinck R and Poorter G de. 2001. The Belgian PCB and dioxin incident of January-June 1999: exposure data and potential impact on health. Environ. Health Persp. 109: 265-273.

Llerena J J, Abad E, Caixach J and Rivera J. 2003. An episode of dioxin contamination in feedingstuff: the choline chloride case. Chemosphere. 53: 679-683.

Malisch R. 2000. Increase of the PCDD/F-contamination of milk, butter and meat samples by use of contaminated citrus pulp. Chemosphere. 40: 1041-1053.

SCF. 2001. Opinion of the Scientific Committee on Food on the risk assessment of dioxins and dioxin-like PCBs in food. Scientific Committee on Food report CS/CNTM/DIOXIN/20 final, http://europa.eu.int/comm/food/fs/sc/scf/out90_en.pdf.

Tlustos C. 2009a. The dioxin contamination incident in Ireland 2008. Organ. Comp. 71: 11721176. 
Tlustos C. 2009b. The dioxin crisis in Ireland 2008 - challenges in risk management and risk communication. Organ. Comp. 71: 1169-1171.

\section{Acknowledgements}

The authors thank Tanja Vervust for the extended tracing suppliers of pig skin and they are grateful to the RoI authorities for releasing the profiling information.

The research leading to these results has received funding from the European community's Seventh Framework Programme FP7/2007-2013 under grant agreement n 228821 


\section{Tables}

Table 1:

Tracing data for the origin of the carcasses deboned at Company B at October $13^{\text {th }}$.

Table 2:

Country of origin of the processed pig skin for the production of fat and gelatine at the

Belgian production plant

Table 3:

Levels of dioxins and PCBs in pooled RoI pork samples and in bread crumbs. Levels for dioxins and dl-PCBs in $\mathrm{pg} \mathrm{g}^{-1}$ fat or crumbs, levels of indicator PCBs in $\mathrm{ng} \mathrm{g}^{-1}$ fat or crumbs. Total levels in pg TEQ $\mathrm{g}^{-1}$ fat, based on $\mathrm{WHO}_{1998}-\mathrm{TEFs}$. Included is also the ratio between the sum of the 6 indicator PCBs and the PCDD/F-TEQ level. 


\section{Figures}

Figure 1: Level of PCDD/Fs in fat in the Belgian gelatine production plant at date of sampling (A) in comparison with countries of origin of the pig skins in the batches where the country of
origin was traced (B).

Figure 2: Patterns of dioxins (A), dioxin-like PCBs (B) and indicator PCBs (C) in 3 meat samples, the highest fat sample from the gelatine plant, the bread crumbs and a sample of oil used for the drying process (indicator PCBs only). PCB 123 could not be determined in crumbs due to interfering substances. 

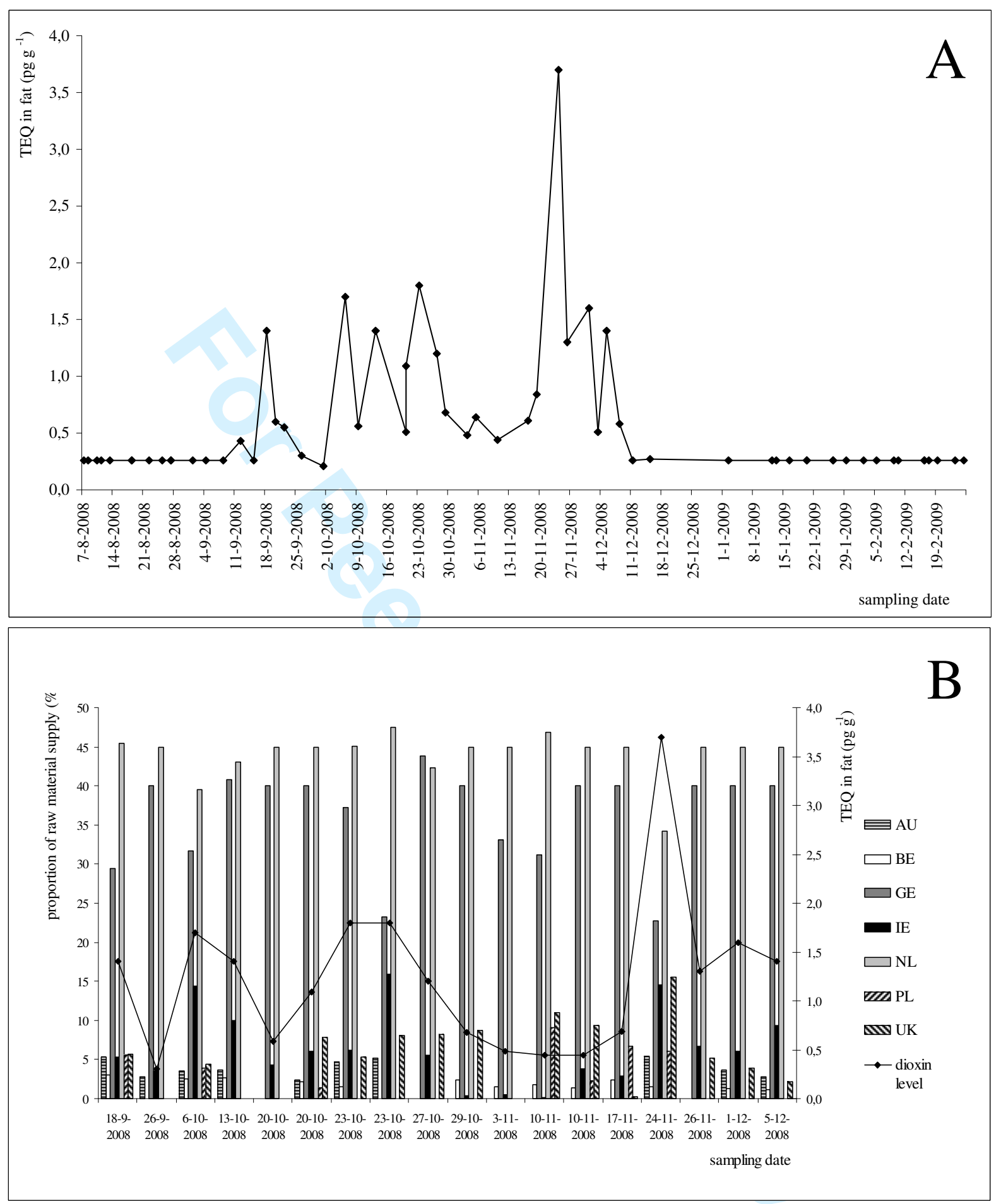

Figure 1: Level of PCDD/Fs in fat in the Belgian gelatine production plant at date of sampling (A) in comparison with countries of origin of the pig skins in the batches where the country of origin was traced (B). 

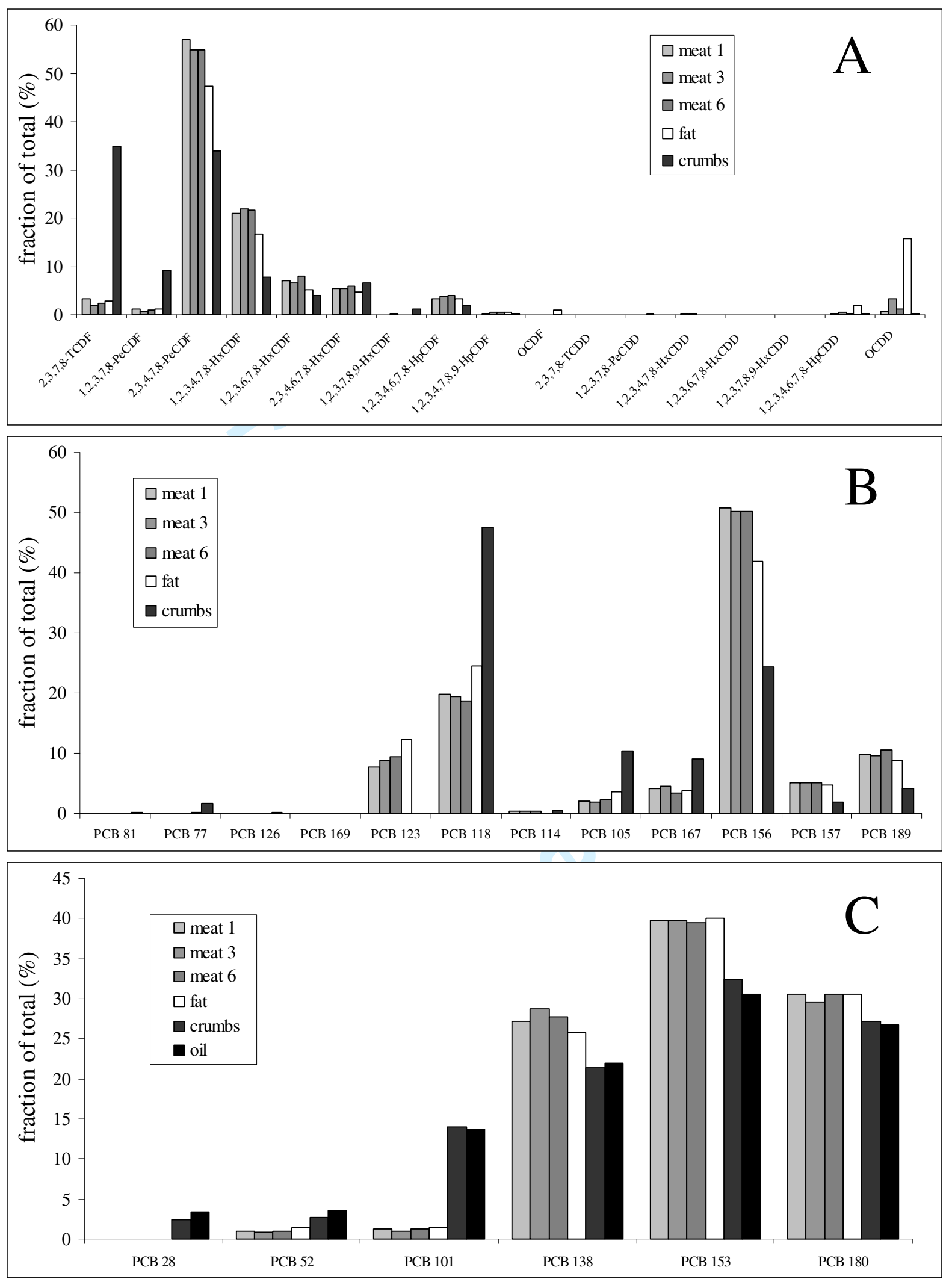

Figure 2: Patterns of dioxins (A), dioxin-like PCBs (B) and indicator PCBs (C) in 3 meat samples, the highest fat sample from the gelatine plant, the bread crumbs and a sample of oil used for the drying process (indicator PCBs only). PCB 123 could not be determined in crumbs due to interfering substances. 
Table 1: Tracing data for the origin of the carcasses deboned at Company B at October $13^{\text {th }}$.

\begin{tabular}{lcccc}
\hline $\begin{array}{l}\text { Country of origin, } \\
\text { slaughterhouse }\end{array}$ & $\begin{array}{c}\text { Number } \\
\text { of } \\
\text { carcasses } \\
\text { deboned }\end{array}$ & $\begin{array}{c}\text { Carcasses from } \\
\text { slaughter date(s) }\end{array}$ & $\begin{array}{c}\text { Numbers of } \\
\text { farms that } \\
\text { supplied at } \\
\text { these dates }\end{array}$ & $\begin{array}{c}\text { Total number } \\
\text { of sows } \\
\text { slaughtered }\end{array}$ \\
\hline NL, Company B & 361 & $10-10-2008$ & 124 & 361 \\
BE, Company B & 23 & $10-10-2008$ & 5 & 23 \\
NL, Slaughterhouse 2 & 2 & $9-10-2008$ & 51 & 419 \\
DE, Slaughterhouse 1 & 110 & $8 / 9 / 10-10-$ & 35 & 121 \\
DE, Slaughterhouse 2 & 1 & $7 / 8-10-2008$ & 74 & 178 \\
UK, England & 136 & not reported & 7 & 220 \\
UK, Northern Ireland & 140 & not reported & 3 & Not reported \\
IRL, Republic of Ireland & 144 & $10-10-2008$ & 39 & Not reported \\
IT, Northern Italy & 132 & Not reported & 4 & 152 \\
\hline Total & 1049 & & 342 & \\
\hline
\end{tabular}


Table 2: Country of origin of the processed pig skin for the production of fat and gelatine at the Belgian production plant

\begin{tabular}{ccc}
\hline Country of origin & $\begin{array}{c}\# \\
\text { suppliers }\end{array}$ & $\begin{array}{c}\text { Avg.\% of } \\
\text { supply }\end{array}$ \\
\hline NL & 13 & $40 \%$ \\
GE & 13 & $40 \%$ \\
RoI & 2 & $7 \%$ \\
UK & 2 & $7 \%$ \\
AU & 2 & $4 \%$ \\
PL & 2 & $3 \%$ \\
BE & 2 & $2 \%$ \\
\hline
\end{tabular}


Table 3. Levels of dioxins and PCBs in pooled RoI pork samples and in bread crumbs. Levels for dioxins and dl-PCBs in $\mathrm{pg} \mathrm{g}^{-1}$ fat or crumbs, levels of indicator PCBs in $\mathrm{ng} \mathrm{g}^{-1}$ fat or crumbs. Total levels in pg TEQ $\mathrm{g}^{-1}$ fat, based on $\mathrm{WHO}_{1998}$-TEFs. Included is also the ratio between the sum of the 6 indicator PCBs and the PCDD/F-TEQ level.

\begin{tabular}{lrrrrrrrr} 
& meat 1 & meat 2 & meat 3 & meat 4 & meat 5 & meat 6 & meat 7 & crumbs \\
\hline PCDD/Fs (pg g ${ }^{-1}$ ) & & & & & & & & \\
& & & & & & & & \\
$2,3,7,8-\mathrm{TCDF}$ & 7.3 & 2.0 & 2.0 & 0.1 & 1.7 & 10.2 & 6.4 & 12876 \\
$1,2,3,7,8-\mathrm{PeCDF}$ & 2.7 & 0.9 & 0.7 & 0.1 & 0.7 & 4.4 & 3.7 & 3394 \\
$2,3,4,7,8-\mathrm{PeCDF}$ & 130.2 & 58.5 & 54.6 & 4.3 & 52.8 & 231.3 & 156.5 & 12552 \\
$1,2,3,4,7,8-\mathrm{HxCDF}$ & 48.0 & 27.8 & 21.8 & 1.6 & 23.3 & 91.4 & 61.8 & 2875 \\
$1,2,3,6,7,8-\mathrm{HxCDF}$ & 15.9 & 9.8 & 6.6 & 0.5 & 7.9 & 33.5 & 25.8 & 1472 \\
$2,3,4,6,7,8-\mathrm{HxCDF}$ & 12.2 & 6.1 & 5.4 & 0.4 & 5.2 & 24.6 & 17.7 & 2431 \\
$1,2,3,7,8,9-\mathrm{HxCDF}$ & 0.1 & 0.1 & 0.1 & $<0.05$ & 0.1 & 0.4 & 0.3 & 402 \\
$1,2,3,4,6,7,8-\mathrm{HpCDF}$ & 7.7 & 5.4 & 3.8 & 0.4 & 5.4 & 17.3 & 12.3 & 695 \\
$1,2,3,4,7,8,9-\mathrm{HpCDF}$ & 0.7 & 0.4 & 0.4 & $<0.05$ & 0.4 & 1.8 & 0.9 & 124 \\
OCDF & 0.1 & 0.2 & $<0.10$ & $<0.10$ & $*$ & $*$ & 0.1 & 38 \\
$2,3,7,8-\mathrm{TCDD}$ & 0.1 & $<0.05$ & $<0.05$ & $<0.05$ & $<0.05$ & 0.2 & 0.1 & 11 \\
$1,2,3,7,8-\mathrm{PeCDD}$ & 0.2 & 0.1 & 0.1 & $<0.05$ & 0.1 & 0.6 & 0.3 & 34 \\
$1,2,3,4,7,8-\mathrm{HxCDD}$ & 0.5 & 0.3 & 0.2 & 0.1 & 0.4 & $*$ & 0.6 & 21 \\
$1,2,3,6,7,8-\mathrm{HxCDD}$ & 0.2 & 0.2 & 0.1 & 0.1 & $*$ & 0.5 & 0.3 & 22 \\
$1,2,3,7,8,9-\mathrm{HxCDD}$ & $<0.05$ & $<0.05$ & $<0.05$ & $<0.05$ & $<0.05$ & $<0.05$ & $<0.05$ & 10 \\
$1,2,3,4,6,7,8-\mathrm{HpCDD}$ & 0.6 & 0.4 & 0.4 & 0.2 & $*$ & 0.7 & 0.5 & 67 \\
OCDD & 1.8 & 1.5 & 3.3 & 4.7 & 4.2 & 5.0 & 2.0 & 50 \\
& & & & & & & & \\
\hline
\end{tabular}

dl-PCBs $\left(\mathrm{pg} \mathrm{g}^{-1}\right)$

\begin{tabular}{lrrrrrrrr} 
PCB 81 & 0.2 & 0.1 & 0.1 & 0.1 & 0.1 & 0.3 & 0.2 & 164 \\
PCB 77 & 1.6 & 0.6 & 0.7 & 0.3 & 0.6 & 2.2 & 1.3 & 2866 \\
PCB 126 & 1.6 & 0.7 & 0.7 & 0.2 & 0.7 & 2.8 & 1.4 & 294 \\
PCB 169 & 3.2 & 2.3 & 1.5 & 0.4 & 2.5 & 5.5 & 3.7 & 50 \\
PCB 123 & 555.0 & 274.0 & 271.0 & 23.8 & 498.0 & 1270.0 & 590.0 & $*$ \\
PCB 118 & 1410.0 & 832.0 & 597.0 & 107.0 & 629.0 & 2500.0 & 1810.0 & 80500 \\
PCB 114 & 22.3 & 13.4 & 11.2 & $<10.0$ & 11.6 & 40.5 & 29.7 & 1050 \\
PCB 105 & 142.0 & 80.0 & 55.6 & 14.2 & 58.1 & 297.0 & 195.0 & 17600 \\
PCB 167 & 291.9 & 140.5 & 140.0 & 11.5 & 117.0 & 455.0 & 308.0 & 15500 \\
PCB 156 & 3610.0 & 2600.0 & 1540.0 & 143.0 & 2790.0 & 6750.0 & 4420.0 & 41200 \\
PCB 157 & 365.0 & 265.0 & 158.0 & 17.4 & 295.0 & 696.0 & 438.0 & 3330 \\
PCB 189 & 703.0 & 537.0 & 296.0 & 25.6 & 616.0 & 1410.0 & 854.0 & 6970 \\
& & & & & & & & \\
WHO-PCDD/F-TEQ & 74.1 & 34.2 & 31.2 & 2.5 & 30.5 & 132.9 & 90.3 & 8510 \\
WHO-PCB-TEQ & 2.5 & 1.7 & 1.1 & 0.1 & 1.8 & 4.6 & 3.0 & 64 \\
WHO-PCDD/F-PCB-TEQ & 76.5 & 35.9 & 32.2 & 2.7 & 32.4 & 137.5 & 93.3 & 8574 \\
& & & & & & & & \\
\hline indicator-PCBs (ng g ${ }^{-1}$ ) & & & & & & & & \\
& & & & & & & & \\
PCB 28 & $<0.1$ & $<0.1$ & $<0.1$ & $<0.1$ & $<0.1$ & $<0.1$ & $<0.1$ & 33.8 \\
PCB 52 & 1.4 & 0.5 & 0.5 & $<0.1$ & 0.9 & 2.5 & 1.5 & 38.9 \\
PCB 101 & 1.8 & 0.7 & 0.6 & $<0.1$ & 0.9 & 3.2 & 2.1 & 197 \\
PCB 153 & 53.9 & 41.2 & 23.6 & 2.2 & 47.1 & 105.0 & 64.0 & 458 \\
PCB 138 & 36.9 & 26.7 & 17.1 & 1.7 & 35.0 & 73.9 & 45.7 & 302 \\
PCB 180 & 41.4 & 31.0 & 17.6 & 1.6 & 36.5 & 81.4 & 49.3 & 383 \\
Sum indicator PCBs & & & & & & & & \\
\hline & 135.5 & 100.3 & 59.4 & 5.7 & 120.5 & 266.2 & 162.7 & 1413 \\
ind-PCBs / PCDD/F-TEQ & 1829 & 2932 & 1908 & 2257 & 3946 & 2003 & 1802 & 166
\end{tabular}

